\title{
Experimental Study on a New Corrosion and Scale Inhibitor
}

\section{Defang Zeng, Huan Yan}

School of Resource and Environmental Engineering, Wuhan University of Technology, Wuhan, China.

Email: 542785846@qq.com

Received February $5^{\text {th }}, 2013$; revised March $6^{\text {th }}, 2013$; accepted April $5^{\text {th }}, 2013$

Copyright (C) 2013 Defang Zeng, Huan Yan. This is an open access article distributed under the Creative Commons Attribution License, which permits unrestricted use, distribution, and reproduction in any medium, provided the original work is properly cited.

\begin{abstract}
The mixture consisted of benzotriazole (BTA), chitosan (CTS), polyacrylic acid and zinc salt has been investigated as a corrosion and scale inhibitor of A3 carbon steel in cooling water. The scale and corrosion inhibition efficiency was evaluated by static anti-scaling teat together with rotary coupon test. Compared with the phosphorus corrosion and scale inhibitor, the corrosion inhibition rate and scale inhibition rate of it increased respectively by $2.51 \%$ and $1.16 \%$. As the corrosion and scale inhibitor is phosphate-free, it won't cause eutrophication, considering the product performance and environmental influence, the phosphate-free corrosion and scale inhibitor is superior to the traditional one.
\end{abstract}

Keywords: Corrosion and Scale Inhibitor; Scale Inhibition Performance; Corrosion Inhibition

\section{Introduction}

With the development of economy, the consumption of industrial cooling water is increasing rapidly. Because of evaporation, concentration, temperature rise and other reasons in the process of operation, dissolved salts will be separated out from cooling water and it can adsorb in pipe wall and equipment in the form of scale, the metal surface may form electrochemical corrosion because of irregularity, both of them will affect the equipment, service life of pipelines and use efficiency. Therefore people have to pay more attention to the treatment of the circulating cooling water [1,2].

Recently, dosing reagents into circulating cooling water is the most common method, and through the role of the pharmacy, the corrosion and scaling problem in the pipes will be solved effectively [3-6]. Now, phosphorus products are widely used in cooling water system. Because they can easily cause environmental pollution, an intense research effort is being undertaken to look for the replacement of phosphorus products by more environmentally friendly products [7-12]. The previous work has shown that Chitosan is a natural polymer material which has good resistance scale effect; benzotriazole and zinc salts both have corrosion inhibition effect.

The present work aims to study the performance of a new corrosion and scale inhibitor mixed by chitosan
(CTS), polyacrylic acid, benzotriazole (BTA) and zinc salt in cooling water. The best formula has been found and it has obvious economic and environmental benefits.

\section{Experimental}

\subsection{Materials and Instruments}

Test specimens were $50 \times 25 \times 2 \mathrm{~mm}$ sheets prepared from A3 carbon steel. The exposed surfaces degreased with acetone. The corrosion products were eliminated by HCL at $10 \%$ for 3 minutes before tested.

The chitosan was made from shrimp. After removing impurities, cleaning the selected shrimp by water, soaking it into $10 \%$ hydrochloric acid for 3 days in order to remove the calcium in it. After filtration and washing, placed it into $10 \% \mathrm{NaOH}$, heated it to boiling for 3 hours, oxidated it with $4 \% \mathrm{KMnO}_{4}$ for 2 hours, then added $0.2 \% \mathrm{NaHSO}_{3}$ in order to fade the colour of $\mathrm{KMnO}_{4}$ completely. Finally dry it to get white flakes of chitin. Placed $5 \mathrm{~g}$ chitin into a three-necked flask equipped with $50 \mathrm{~mL} 50 \%$ sodium hydroxide solution, keeping the temperature $100^{\circ} \mathrm{C}$, stirring speed $50 \mathrm{r} / \mathrm{min}$, stirring time 50 min under the conditions of the deacetylation reaction, then filtration, washing and drying to get chitosan products, finally taking the chitosan products to prepare CTS working fluid of $0.02 \%$. 


\subsection{Experimental Methods}

\subsubsection{Rotating Hanging Plate Experiment}

Corrosion inhibition efficiency was determined by weight loss of the tested specimens using rotating hanging plate method [13], afterward, the instruments used was RCC-type I rotate hang piece of test, the experiment was achieved in laboratory configuration water (Table 1) at temperature $45^{\circ} \mathrm{C} \pm 1^{\circ} \mathrm{C}$, time $72 \mathrm{~h}$ and rotation speed $75 \mathrm{r} / \mathrm{min}$. The corrosion rate $X$ and corrosion inhibition rate $\eta$ were calculated respectively by Types (1) and (2):

$$
X=\frac{87600\left(m_{1}-m_{2}\right)}{s \rho t}
$$

where $m_{1}$ and $m_{2}$ were the quality of A3 carbon steel before and after the test respectively. $s$ is the surface area, $\mathrm{cm}^{2} ; \rho$ is the density. $\mathrm{g} / \mathrm{cm} ; t$ is the experimental time, $h$

$$
\eta=\frac{X_{0}-X_{1}}{X_{0}} \times 100 \%
$$

where $X_{0}$ and $X_{1}$ were the corrosion rate without and with the corrosion and scale inhibitor.

\subsubsection{Static Scale Inhibition Experiment}

Scale inhibition efficiency was tested by "Calcium carbonate deposition method" [14]. The principle was to heat water samples with and without the scale and corrosion inhibitor, then determined the concentration of $\mathrm{Ca}^{2+}$ and calculated the inhibition rate. The experiment was achieved at temperature $80^{\circ} \mathrm{C} \pm 1^{\circ} \mathrm{C}$ and time $10 \mathrm{~h}$. Scale inhibition rate $\eta$ was calculated by Type (3):

$$
\eta=\frac{\rho_{1}-\rho_{0}}{\rho_{2}-\rho_{0}} \times 100 \%
$$

where $\rho_{0}$ and $\rho_{1}$ were the $\mathrm{Ca}^{2+}$ concentration without and with corrosion and scale inhibitor, while $\rho_{2}$ was $\mathrm{Ca}^{2+}$ concentration before experimenting.

\section{Results and Discussion}

\subsection{Best Formula of the New Phosphate-Free Corrosion and Scale Inhibitor}

Adequate experimental studies have been made to determine the preliminary formula. In this paper, Table 2 shows the four factors and their levels. The final formula would been determined by further experiments.

The best formula would be determined through orthogonal experiment used calcium carbonate deposition method (GB/T16632-2008). The initial $\mathrm{Ca}^{2+}$ concentra-

Table 1. Water quality index.

\begin{tabular}{cccccc}
\hline $\begin{array}{l}\mathrm{Ca}^{2+} / \\
\mathrm{mg} / \mathrm{L}\end{array}$ & $\begin{array}{c}\text { conductance/ } \\
\mu \mathrm{S} / \mathrm{cm}\end{array}$ & $\begin{array}{c}\text { total hardness/ total alkalinity/ } \\
\mathrm{mg} / \mathrm{L}\end{array}$ & $\begin{array}{c}\mathrm{mH} / \mathrm{L} \\
\mathrm{m}\end{array}$ & $\begin{array}{c}\mathrm{Cl}^{-} / \\
\mathrm{mg} / \mathrm{L}\end{array}$ \\
\hline 134 & 357 & 7.8 & 7.3 & 7.5 & 221 \\
\hline
\end{tabular}

tion was $240 \mathrm{mg} \cdot \mathrm{L}^{-1}$, scale inhibition rate was calculated by Type (3). Table 3 shows the importance of factors as polyacrylic acid $>\mathrm{CTS}>\mathrm{BTA}>$ zinc salt, the best formula was $\mathrm{B}_{3} \mathrm{C}_{2} \mathrm{~A}_{2} \mathrm{D}_{2}$.

\subsection{Corrosion Inhibition Performance Analysis}

Table 4 contains the corrosion inhibition efficiency of A3 carbon steel samples in colling water with OPPM, 10 PPM, 20 PPM, 30 PPM and 40 PPM corrosion and scale inhibitor .In all cases the typical behavior was observed, corrosion inhibitor rate of the phosphorus-free corrosion inhibitor increased as the concentration elevated. The corrosion inhibition rate could reach $96.14 \%$ when the dosage was 30 PPM .

\subsection{Scale Inhibition Performance Analysis}

Table 5 shows the scale inhibition performance respectively with 0 PPM, 10 PPM, 20 PPM, 30 PPM and 40 PPM corrosion and scale inhibitor. The scale inhibition rate increased with the concentration elevated. The scale inhibition rate could reach $94.48 \%$ when the dosage was 30 PPM.

Table 2. Factors and levels of orthogonal experiment.

\begin{tabular}{|c|c|c|c|c|c|}
\hline \multirow{2}{*}{ Sample } & \multicolumn{4}{|c|}{ Level } & \multirow{2}{*}{$\begin{array}{l}\text { Average scale } \\
\text { inhibition rate }\end{array}$} \\
\hline & A & B & $\mathrm{C}$ & $\mathrm{D}$ & \\
\hline 1 & 1 & 1 & 1 & 1 & $82.34 \%$ \\
\hline 2 & 1 & 2 & 2 & 2 & $91.23 \%$ \\
\hline 3 & 1 & 3 & 3 & 3 & $93.32 \%$ \\
\hline 4 & 2 & 1 & 2 & 3 & $92.26 \%$ \\
\hline 5 & 2 & 2 & 3 & 1 & $84.40 \%$ \\
\hline 6 & 2 & 3 & 1 & 2 & $92.93 \%$ \\
\hline 7 & 3 & 1 & 3 & 2 & $84.43 \%$ \\
\hline 8 & 3 & 2 & 1 & 3 & $87.28 \%$ \\
\hline 9 & 3 & 3 & 2 & 1 & $91.15 \%$ \\
\hline $\mathrm{k} 1$ & $88.96 \%$ & $86.34 \%$ & $87.51 \%$ & $85.96 \%$ & \\
\hline $\mathrm{k} 2$ & $89.86 \%$ & $87.63 \%$ & $91.54 \%$ & $92.36 \%$ & \\
\hline k3 & $87.64 \%$ & $92.49 \%$ & $87.38 \%$ & $90.95 \%$ & \\
\hline $\mathrm{R}$ & $2.22 \%$ & $6.15 \%$ & $4.16 \%$ & $1.41 \%$ & \\
\hline Factor & 3 & 1 & 2 & 4 & \\
\hline
\end{tabular}

\begin{tabular}{cccc}
\hline \multirow{2}{*}{ Experiment factors } & \multicolumn{3}{c}{ Level } \\
\cline { 2 - 4 } & 1 & 2 & 3 \\
\hline BTA (A) & 0.05 & 0.10 & 0.15 \\
Polyacrylic acid (B) & 2 & 4 & 6 \\
CTS (C) & 8 & 10 & 12 \\
Zinc salt (D) & 0.8 & 1.0 & 1.2 \\
\hline
\end{tabular}

Table 3. Orthogonal experiment of $\mathrm{L}_{9}\left(3^{4}\right)$. 
Table 4. Results of corrosion inhibition rate.

\begin{tabular}{|c|c|c|c|c|c|c|}
\hline $\begin{array}{c}\text { Ethephon } \\
\text { concentration (ppm) }\end{array}$ & $\begin{array}{l}\text { Hanging plate } \\
\text { number }\end{array}$ & $\begin{array}{l}\text { Quality before } \\
\text { experiment } m_{1}(\mathrm{~g})\end{array}$ & $\begin{array}{l}\text { Quality after } \\
\text { experiment } m_{2}(\mathrm{~g})\end{array}$ & $\begin{array}{c}\text { Average } \\
\text { weightlessness (g) }\end{array}$ & $\begin{array}{c}\text { Corrosion } \\
\text { Inhibition rate (\%) }\end{array}$ & $\begin{array}{l}\text { Corrosion } \\
\text { rate }(\mathrm{mm} / \mathrm{a})\end{array}$ \\
\hline \multirow{2}{*}{0} & 1 & 18.2532 & 17.9579 & \multirow{2}{*}{0.2954} & \multirow{2}{*}{0.00} & \multirow{2}{*}{1.6336} \\
\hline & 2 & 18.2367 & 17.9412 & & & \\
\hline \multirow{2}{*}{10} & 3 & 17.5180 & 17.4707 & \multirow{2}{*}{0.0382} & \multirow{2}{*}{87.10} & \multirow{2}{*}{0.2112} \\
\hline & 4 & 17.4332 & 17.4041 & & & \\
\hline \multirow{2}{*}{20} & 5 & 18.1130 & 18.0853 & \multirow{2}{*}{0.0225} & \multirow{2}{*}{92.38} & \multirow{2}{*}{0.1244} \\
\hline & 6 & 19.3213 & 19.3040 & & & \\
\hline \multirow{2}{*}{30} & 7 & 17.1954 & 17.1839 & \multirow{2}{*}{0.0114} & \multirow{2}{*}{96.14} & \multirow{2}{*}{0.0630} \\
\hline & 8 & 18.1873 & 18.1760 & & & \\
\hline \multirow{2}{*}{40} & 9 & 17.1854 & 17.1736 & \multirow{2}{*}{0.0116} & \multirow{2}{*}{96.07} & \multirow{2}{*}{0.0641} \\
\hline & 10 & 18.1754 & 18.1634 & & & \\
\hline
\end{tabular}

Table 5. Test results of scale inhibition.

\begin{tabular}{cccc}
\hline $\begin{array}{c}\text { Ethephon } \\
\text { concentration } \\
(\mathrm{mg} / \mathrm{L})\end{array}$ & $\begin{array}{c}\mathrm{Ca}^{2+} \text { concentration } \\
\text { before experiment } \\
(\mathrm{mg} / \mathrm{L})\end{array}$ & $\begin{array}{c}\mathrm{Ca}^{2+} \text { concentration } \\
\text { after experiment } \\
(\mathrm{mg} / \mathrm{L})\end{array}$ & $\begin{array}{c}\text { Scale } \\
\text { inhibition rate } \\
(\%)\end{array}$ \\
\hline 0 & 240 & 157.23 & 0 \\
10 & 240 & 229.45 & 87.25 \\
20 & 240 & 234.56 & 93.43 \\
30 & 240 & 235.43 & 94.48 \\
40 & 240 & 232.23 & 90.61 \\
\hline
\end{tabular}

\subsection{Effect of $\mathrm{Ca}^{2+}$ Concentration}

The relateship between inhibition rate and $\mathrm{Ca}^{2+}$ concentration was tested at scale inhibitor concentration 30 $\mathrm{PPM}, \mathrm{pH} 7$, temperature $80^{\circ} \mathrm{C}$ and heating temperature 10 hours. Figure 1 showed that scale inhibition rate increased with $\mathrm{Ca}^{2+}$ concentration elevated in the scope of $100 \mathrm{mg} \cdot \mathrm{L}^{-1}$ to $220 \mathrm{mg} \cdot \mathrm{L}^{-1}$, so this corrosion and scale inhibitor was applied to the system of $\mathrm{Ca}^{2+}$ concentration in 100 to $220 \mathrm{mg} \cdot \mathrm{L}^{-1}$.

\subsection{Effect of pH Values}

The curves included in Figure 2 allowed to evaluate $\mathrm{pH}$ related to corrosion and scale inhibition. Calcium carbonate deposition method (GB/T16632-2008) was used. Figure 2 showed that $\mathrm{pH}$ had great influence on corrosion and scale rate. Scale inhibition rate was less than $93 \%$ when $\mathrm{pH}$ was less than 7 , it could reach $94.48 \%$ while the $\mathrm{pH}$ value was between 7 and 8 , after PH researched 8 , scale inhibition rate declined. In alkaline system calcium carbonate will generated $\mathrm{Ca}\left(\mathrm{HCO}_{3}\right)_{2}$ and $\mathrm{OH}^{-}$, they would make scale inhibition rate declined. In acidic condition, a protective and dense calcium carbonate scale layer could not been easily formed on surface of A3 carbon steel, zinc salt would sediment and influence the corrosion inhibition rate on alkaline conditions when $\mathrm{pH}$ was greater than 8 [15-17]. This showed the corro-

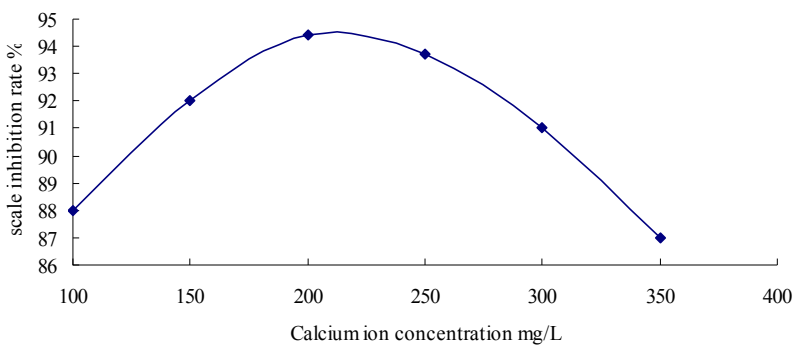

Figure 1. Influence of $\mathrm{Ca}^{2+}$ Concentration to scale inhibition rate.

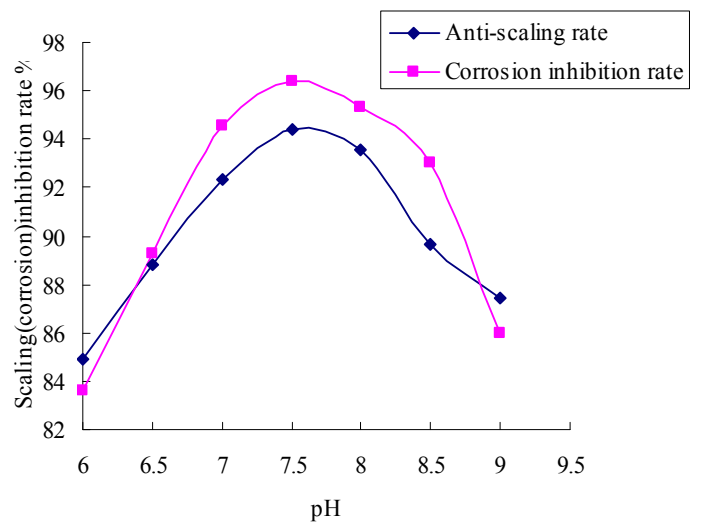

Figure 2. Influence of $\mathrm{pH}$ to corrosion and scale inhibition rate.

sion inhibitor was applicable to the system in which $\mathrm{pH}$ value was between 7 to 8 .

Table 6 showed the comparisons between the new and traditional corrosion and scale inhibitors were showed the corrosion inhibition rate and scale inhibition rate of the optimum formula increased respectively by $2.51 \%$ and $1.16 \%$. It is an ideal corrosion inhibitor with phosphorus - free and would not cause water eutrophication.

\section{Conclusions}

From the whole set of datas obtained in this study, it can 
Table 6. Comparisons between the new and traditional corrosion inhibitors.

\begin{tabular}{ccccc}
\hline Number & $\begin{array}{c}\text { Corrosion } \\
\text { inhibition } \\
\text { rate }(\%)\end{array}$ & $\begin{array}{c}\text { Scale } \\
\text { inhibition } \\
\text { rate }(\%)\end{array}$ & $\begin{array}{c}\text { Optimal dosing } \\
\text { quantity (ppm) }\end{array}$ & $\begin{array}{c}\text { Cost } \\
(\text { yuan/t) }\end{array}$ \\
\hline $\begin{array}{c}\text { Optimum } \\
\text { formula } \\
\text { Traditional } \\
\text { corrosion and } \\
\text { scale inhibitor }\end{array}$ & 96.14 & 94.48 & 30 & 0.42 \\
\hline
\end{tabular}

be concluded that a phosphorus-free corrosion and scale inhibitor consist of benzotriazole (BTA), chitosan (CTS), polyacrylic acid and zinc salt showed a better performance than the traditional one.

Scale and corrosion inhibition rates could reach respectively $96.14 \%$ and $94.48 \%$ when dosage was $30 \mathrm{ppm}$. The phosphorus-free corrosion and scale inhibitor can apply to system at $\mathrm{pH}$ between 7 and 8.1 and $\mathrm{Ca}^{2+}$ concentration between 100 and $220 \mathrm{mg} \cdot \mathrm{L}^{-1}$.

Compared with the traditional one, the corrosion inhibition rate and scale inhibition rate increased respectively by $2.51 \%$ and $1.16 \%$. As the corrosion and scale inhibitor was phosphate-free, it wouldn't cause eutrophication, considering the economic cost, product performance and environmental influence, the new phosphate-free corrosion and scale inhibitor was significantly superior to the traditional one and had obvious environmental benefits.

\section{Acknowledgements}

This project was supported by Ministry of Science and Technology in China of SME Technology Innovation Foundation and Department of Science and Technology in Hubei Province, China of Science and Technology Research Foundation, express our thanks to those provided guidance and assistance.

\section{REFERENCES}

[1] R. Touir, N. Dkhireche, M. Ebn Touhami, M. Lakhrissi, B. Lakhrissi and M. Sfaira, "Corrosion and Scale Processes and Their Inhibition in Simulated Cooling Water Systems by Monosaccharides Derivatives: Part I: EIS Study," Desalination, Vol. 249, No. 3, 2009, pp. 922-928. doi:10.1016/j.desal.2009.06.068

[2] M. A. Quraishi, A. Singh and V. K. Singh, "Green Approach to Corrosion Inhibition of Mild Steel in Hydrochloric Acid and Sulphuric Acid Solutions by the Extract of Murraya koenigii Leaves" Materials Chemistry and Physics, Vol. 122, No. 1, 2010, pp. 114-122. doi:10.1016/j.matchemphys.2010.02.066

[3] P. Kalaiselvi, S. Chellammal, et al., "Artemisia Pallens as Corrosion Inhibitor for Mild Steel in HCl Mediun," Materials Chemistry and Physics, Vol. 120, No. 2, 2010, pp. 643-648. doi:10.1016/j.matchemphys.2009.12.015
[4] R. Touir, N. Dkhireche, M. Ebn Touhami, M. Sfaira, O. Senhaji, J. J. Robin, B. Boutevin and M. Cherkaoui, "Study of Phosphonate Addition and Hydrodynamic Conditions on Ordinary Steel Corrosion Inhibition in Simulated Cooling Water," Materials Chemistry and Physics, Vol. 122, No. 1, 2010, pp. 1-9. doi:10.1016/j.matchemphys.2010.02.063

[5] L. G. Qing, H. J. Yi, Z. Y. Ming, et al., "Acrylic AcidAllylpolyethoxy Carboxylate Copolymer Dispersant for Calcium Carbonate and Iron(III) Hydroxide Scales in Cooling Water Systems," Tenside Surfactants Detergents, Vol. 49, No. 3, 2012, pp. 216-224.

[6] D. Lzydor and F. Piotr, "Industrial Cooling Water Systems. Exploitation and Environmentally Benign Total Inhibitive Protection," Przemysl Chemiczny, Vol.90, No. 5, 2011, pp. 737-741.

[7] X. Y. He, Y. H. Cheng, L. X. Wang and P. Huo, "Study of Corrosion and Scale Inhibition Performances of PASP Complex Water Treatment Agents," CAS, Vol. 30, No. 8, pp. 64-66.

[8] A. Y. Hu, "Analysis of Water and Energy Saving Measures in Industrial Circulating Cooling Water System," Industry Water and Wastewater, Vol. 42, No. 3, 2011, pp. 1-4.

[9] R. Touir, M. Cenoui, M. El Bakri and M. Ebn Touhami, "Sodium Gluconate as Corrosion and Scale Inhibitor of Ordinary Steel in Simulated Cooling Water," Corrosion Science, Vol. 50, No. 6, 2008, pp. 1530-1537. doi:10.1016/j.corsci.2008.02.011

[10] B. Labriti, N. Dkhireche, R. Touir, M. Ebn Touhami, M. Sfaira, A. El Hallaoui, B. Hammouti and A. Alami, "Synergism in Mild Steel Corrosion and Scale Inhibition by a New Oxazoline in Synthetic Cooling Water," Arabian Journal for Science and Engineering, Vol. 37, No. 5, 2012, pp. 1293-1303.

doi:10.1007/s13369-012-0257-7

[11] A. Weisenburger, G. Müller, A. Heinzel, A. Jianu, H. Muscher and M. Kieser, "Corrosion, Al Containing Corrosion Barriers and Mechanical Properties of Steels Foreseen as Structural Materials in Liquid Lead Alloy Cooled Nuclear Systems," Nuclear Engineering and Design, Vol. 241, No. 5, 2011, pp. 1329-1334. doi:10.1016/j.nucengdes.2010.08.005

[12] L.-J. Gao, J.-Y. Feng, B. Jin, Q.-N. Zhang, T.-Q. Liu, Y.Q. Lun and Z.-J. Wu, "Carbazole and Hydroxy GroupsTagged Poly (Aspartic Acid) Scale Inhibitor for Cooling Water System," Chemistry Letters, Vol. 40, No. 12, 2011, pp. 1392-1394. doi:10.1246/cl.2011.1392

[13] GB/T 18175-2000, "Water Treatment Agent Corrosion Inhibition Performance of the Determination of Rotation Coupon Method."

[14] GB/T 16632-2008, "Performance of Water Treatment Agent and Scale Determination of Calcium Carbonate Deposition (CVD)."

[15] X. P. Ouyang, X. Q. Qiu, H. M. Lou and D. J. Yang, "Corrosion and Scale Inhibition Properties of Sodium Lignosulfonate and Its Potential Application in Recirculating Cooling Water System," Industrial \& Engineering Chemistry Research, Vol. 45, No. 16, 2006, pp. 5716- 
5721. doi:10.1021/ie0513189

[16] Y. Sürme, A. Ali Gürten and E. Bayol "Corrosion Behavior of Mild Steel in the Presence of Scale Inhibitor in Sulfuric Acid Solution," Protection of Metals and Physical Chemistry of Surfaces, Vol. 47, No. 1, 2011, pp.
117-120

[17] D. Hasson, H. Shemer and A. Sher, "State of the Art of Friendly 'Green' Scale Control Inhibitors," Industrial \& Engineering Chemistry Research, Vol. 50, No. 12, 2011, pp. 7601-7607. doi:10.1021/ie200370v 